\title{
The Application of Federal Character Principle and Its Implication on Service Delivery in Nigerian Federal Civil Service
}

\author{
Igbokwe-Ibeto Chinyeaka Justine (Corresponding author) \\ Department of Public Administration, Faculty of Management Sciences \\ Nnamdi Azikiwe University, Awka \\ ugochinyerecj@yahoo.co.uk
}

Agbodike Flowrence Chinelo, Anazodo Rosemary Ogomegbulam

Department of Public Administration, Faculty of Management Sciences

Nnamdi Azikiwe University, Awka

Doi:10.5296/ijhrs.v5i3.7763 URL: http://dx.doi.org/10.5296/ijhrs.v5i3.7763

\begin{abstract}
The study examined the application of federal character principle and its implication on service delivery in Nigerian federal civil service. The Nigerian federal civil service is the bedrock of Nigeria's quest for socio-economic development. However, over the years, service delivery and infrastructural development have remained a hydra headed problem. The study relied heavily on primary and secondary data and multi the stage sampling method was used to select the sample population. The data collected was presented in frequency tables and analysed using descriptive statistics such as mean, table and standard deviation. Pearson chi-square test of goodness was used to test the hypotheses. Findings of the study show that there is a relationship between federal character principle and employees ${ }^{\text {ee }}$ service delivery as well as poor attitude to work by bureaucrats. To achieve efficient service delivery and better attitude to work by civil servants in the service, government should imbibe the prescripts of Marx Weber bureaucratic theory as regards recruitment based on merit, technical competency and qualification, as well as re-examine the reliability and validity of the application of federal character principle or better be situated within grade levels 03-06 while recruitment into the senior officers cadre grade levels $07-17$ and appointments should be strictly based on merit.
\end{abstract}

Keywords: Human Resources, Implication, Nigeria, Sustainability, Service Delivery 


\section{Introduction}

The limitations imposed on recruitment and selection into the federal civil service of Nigeria since independence can be traced to the British administration practice in West Africa. The theoretical operation of the ,Indirect Rule ${ }^{e e}$ system in Nigeria was the involvement of natives in colonial administration. This policy was also given premium by the Parliamentary Selection Committee of 1865 which recommended among others, that Britain should train the natives in her colonies for self government with the view of disengaging from her West African colonies in the nearest future (See for example Maduabum in Igbokwe-Ibeto and Aremu, 2013; Olusanya, 1975;). However, due to the British economic interest in West Africa, the implementation of the policy of gradual withdrawal was rendered ineffective.

The colonial administration of the civil service was affected by the problem of bias in terms of colonial polices and this was an issue of concern for the natives. The colonial administration served the interest of the British as the structure and composition of the civil service was British. Initially, there was exclusion of Africans during the formative years of the colonial civil service but Nigeria's climatic environment was a constraint to the health of British officials. Thus, ecological problems encountered by the British officials and pressure arising from political development and nationalism accelerated the policy of gradual withdrawal and acceptance of the various levels of the Nigerian civil service. The structure of Nigerian Civil Service was created by Sir Hugh Clifford who succeeded Lord Lugard as Governor General of Nigeria. In 1921 he established a Central Secretariat in Lagos and by 1939, provinces administered from Enugu, Ibadan, and Kaduna had their secretariats. The period 1940 - 1950 marked the emergence of Nationalist Nigerian Administration and this represented the proper commencement of the Nigerian Civil Service (Oronsaye, 2009).

The 1958-1959 Solaru Parliamentary Committee on Nigerianization of the civil service suggested among others, the training of Nigerians to administer the civil service. In the discharge of its duties, the committee was of the view that independence would require total control of the federal civil service by Nigerians in order to achieve the task of unity, loyalty, commitment and dedication by officers that would be charged with policy implementation. Thus, by $1^{\text {st }}$ October, 1960, the Federal Civil Service of Nigeria was established. During this period, some Nigerians held prominent positions but fundamental problems such as lack of initiative, lack of expertise, nepotism and inexperience served as impediments to successful implementation of Nigerianization policy. However, this transitive stage created opportunities for qualified Nigerians to be recruited and impact the indigenous culture on a hitherto foreign and British culture dominated and oriented civil service (Olu-Adeyemi, 2009; Olusanya, 1975).

The Nigeria federal civil service comprises the staff used administratively by the central government. The government, whether at the federal, state and local government level is the highest employer of labour. The government uses the civil service to transform her policy objectives and electoral promises into objective results that would benefit the citizenry. Therefore, the right calibre of personnel must be a place to perform these varied functions.

The personnel employed in an organization serve as the hub around which other resources 
revolve. This allows the entire wheel of the organization to turn smoothly in order to perform more effectively, efficiently and economically. This is the reason why the personnel employed in any organization that eventually become the bread-winners of their family and an instrument of progress for the society, have to be well structured (Vickerstaff in Mukoro, 2005). In the civil service, for example, governments should ever be self-advised that organization structure does not in itself guarantee service delivery.

The Nigerian federal civil service emphasizes uniformity, standardization, transparency in recruiting competent applicants. Despite these emphasizes, it is perceived that the recruitment and selection process lacks equity and transparency, making it difficult if not impossible to recruit the best qualified applicants for available jobs in the civil service. Recruitment and selection over the years is weighed down by favoritism at the negation of merit and has shifted from qualification of individuals based on job description and specification to man know man basis. This makes recruitment and selection subjective rather than objective.

It has been argued that for an organization to achieve certain degree of success in service delivery, the quality of human resources needs not to be compromised. Because they are needed to coordinate and activate the other resources, human resources are the main instrument for the attainment of organizational objectives. It is in this regard that (Oshionebo, 1992:97) citing Rensis Likert cited in succinctly posits that:

All activities of any enterprise are initiated and determined by the persons that make up that institution. Plants, offices, computers, automated equipment, and all else that a modern firm uses are unproductive except for human effort and direction. Human beings design or order equipment; they decide where and how to use computers; they modernize or fail to modernize the technology employed; they secure the capital needed and decide on the accounting and fiscal procedures to be used. Every aspect of a firm's activities is determined by the competent, motivated, and general effectiveness of its human organization. Of all the task of management, managing the human component is the central and most important task, because all else depends upon how well it is done.

The federal civil service commission is the institution of government saddled with the responsibility of recruitment and selection of civil servants. Due to diversity of both major and minor ethnic groupings in Nigeria, the Government through Constitution put in place a principle referred to as the "Federal Character Principle or Quota System" which states expressly "the desire of the people of Nigeria to promote national integration, foster national unity and give citizens a sense of belonging as enshrined in Section 14(3\&4) of the 1999 Constitution of the Federal Republic of Nigeria as amended.

The federal civil service comprises the entire staff used by the federal government to transform her policy objectives and electoral promises into objective results that would benefit the citizenry. Therefore, the right calibre of personnel must be in place to perform this varied function. The Nigerian federal civil service emphasizes uniformity, standardization, transparency in recruiting competent applicants (Babaru, 2003). Despite the elaborate provisions in the constitution as well as the civil service rules and regulations as regards the mode of recruitment and selection into the service, the staff composition of most Ministries, 
Departments and Agencies (MDAs) reveals that mediocre and quacks ${ }^{e e}$ get recruited against the tenets of merit and technical competence rooted in Max Weber's ideal bureaucracy (Eneanya, 2009).

In 2007, the size of the Nigerian federal civil service was estimated to be about 220,000 (Briggs, 2007). Despite the large size of federal civil service, the service still manifests signs of poor service delivery due to incompetence of personnel and poor attitude of bureaucrats to work. This perceived anomaly in the federal civil service has provoked a series of studies geared towards ameliorating the ugly situation which scholars have attributed to the familiar challenges of the Nigerian federation. It appears that in spite of efforts of previous administration to transform the civil service and the current efforts of the present regime to effect same, little or nothing have changed in the service in terms of service delivery. The service still remains the same as their performance and attitude to work are still below expectation, efficiency and effectiveness is virtually nil or minimal.

Ultimately, the efficiency and effectiveness of any organization, whether private or public sector largely depend on the calibre of the work force. The availability of a competent and effective work force does not just happen by chance but through an articulated recruitment policy. It should be noted that one of the greatest challenges of Nigerian bureaucracy is non-performance of the civil service. It is therefore, imperative to further interrogate this catalogue of challenges by investigating the federal character principle as regards recruitment in the federal civil service and its implications on workers service delivery.

The broad objective of this study is to examine the effect of federal character principle on was a recruitment policy in Nigerian federal civil service on employees ${ }^{\text {ee }}$ service delivery. The specific objectives include:

1. To examine the effect of federal character principle in the recruitment of civil servants as regards employees ${ }^{\text {ee }}$ service delivery.

2. To examine the effect of federal character principle in the recruitment of federal civil servants as regards employees ${ }^{\text {ee }}$ attitude to work.

\section{Conceptual and Theoretical Framework}

In social and management sciences research, in order to avoid ambiguity in the interpretation and understanding of certain terms, it is customary to begin an academic investigation of this nature by combing the conceptual and theoretical contours of the subject matter of analysis. Though, consensus may not be achieved on the validity or otherwise of such enterprise. Nonetheless, it is an exercise worth pursuing if only to sketch the parameters of the subject matter.

Federal character as a concept belongs to the "tribe" of contested concepts, which generate disputes over their actual meanings. However, in an enterprise of this nature, it is imperative that concepts used in the paper should be clearly defined. According to Olagunju (1987), federal character is a deliberate design to accommodate less dominant but often forcibly expressed interest. Ezeibe (2012) posits that federal character principle involves a deliberate 
plan to construct means of ensuring the proper distribution of amenities and government projects in a country. Implicit in the above definitions is that federal character is introduced where there are observed differences in culture, tradition and inequality either in human, natural or both. Therefore, federal character is a palliative principle aimed at uniting once existed autonomous sub-nationalities through quota system for purposes of equality of opportunities and peaceful co-existence. Ezenwa (1987) and Heirmexy (2011) noted that federal character was introduced for equitable sharing of posts and even distribution of natural and economic resources. In his own contribution, Bodunrin (1989) contends that federal character principle is a political settlement that enables every section of the Nigerian society to be represented in government. He argued, "the new phrase, 'Federal character" in its application and implementation is a mere euphemism for ethnic balancing which has the potential of solving the problem and fear of domination and bring about stability that is needed for development to take place in the country".

The concept of federal character or quota system became part of Nigeria's political vocabulary when it was adopted by the Constitution Drafting Committee in 1975. The phrase Federal Character was first used by the late General Murtala Mohammed in his maiden address to the opening session of the Constitution Drafting Committee on the 18th of October 1975. The federal character principle, according to the committee is the distinctive desire of the Nigerian people to promote national integration, foster national unity as well as giving Nigerian citizens a sense of belonging irrespective of ethnic origin, culture, language or religion diversities. Federal character principle is a quota system and quotas are seen by employers as an unsavory strategy for ratifying the effects of the past 'or present unfair discrimination' (Cascio, 1986).

Recruitment is "a set of activities used to obtain a sufficient number of the right people at the right time from the right places (Nickels, McHuge and McHuge, 1999) and its purpose is to select and place those who best meet the needs of the work place, and to develop and maintain a qualified and adequate work force through which an organization can fulfill its human resource plan. Erasmus, Swanepoeland Schenk, Westhuizen and Wessels (2005) conceive recruitment as "those activities in human resource management which are undertaken in order to attract sufficient job candidates who have the necessary potential, competencies and traits to fill job needs and to assist the civil service organization in achieving its objectives. To achieve organizational goals, the right recruitment must be in place. According to Van der Westhuizen (2005) the recruitment policy stipulates broad guidelines for the way in which a public sector organization intends to deal with recruitment. In brief terms, the recruitment policy must indicate the organization's position concerning the general objectives of recruitment and the principle of equal opportunities in recruitment. For the purposes of this study it is important to provide an example of a recruitment policy. The recruitment, selection and placement of personnel are done in terms of the legal framework applicable to the Nigerian civil service, namely: The Constitution of the Federal Republic of Nigeria 1999 as amended, the Public Service Rules 02201 (FRN, 2000 and 2000 $)$, and Federal Character Principle and Quota System Section 14(3) of the Constitution. 
On the other hand, service delivery simply put is getting public goods and services as expected and as quick as possible by (recipients) citizens. According to Akhakpe (2014), service delivery is the degree and hallmark of excellence in the public service. To Franz (2011), it involves considerable human activity, hence human resource management is important as human element is often the key ingredients of service industries. Public service delivery is one of the major challenges facing developing countries Nigeria inclusive. This should be a top priority of the government if the country is to make substantial progress in socio-economic development.

In Nigeria, a number of problems confront and complicate public service delivery. For example, poor or faulty recruitment policy leads to poor selection of human capital coupled with corruption and decayed infrastructure. The quality and availability of essential services is a major indicator of good governance because public service delivery underpins the social contract between the state and its citizens which in turn portrays a healthy society. With a healthy society, invariably, there tends be an increase in workers productivity. What is civil service and why is it important?

The term civil service is not easily defined. To avoid any ambiguity or misinterpretation, Section 318 of the 1999 constitution as amended, defines the civil service of the Federation as:

Service of the federation in civil capacity as staff of the office of the President, the Vice President, Ministry or Department of the Government of the Federation assigned with the responsibility for any business of the Government of the Federation (FRN, 1999).

The civil service which lies at the centre of Public Administration structure is the major instrument through which Nigerian government, be it colonial, military or civilian administration manage development (Olu-Adeyemi, 2009). Civil servant according to Anazodo, Okoye and Chukwuemeka (2012); Kolawole (2008) is by law and professional orientation required to be apolitical and be loyal to the government of the day. The apolitical character he said; gave the civil servant an advantage of service till retirement age without the fear of vagaries and incessant turn-over in government. The only constraint in this respect is individual decision to resign or retire or be disengaged by disciplinary measures imposed by misconduct or other perceived act of omission or commission. It is a system of service, with recruitment on merit, security of tenure and due recognition of service and merit through timely promotion. This gave the state a class of non-political permanent corps of loyal and industrious officials who form the backbone of Public Administration (Basu, 2004). In Nigeria, the civil service is the nerve center on which policy implementation hinges, apart from its strategic advisory role in policy formulation. It is the civil service that provides the substantial goods and services needed as catalyst for development by both public and private sectors of the economy.

The federal character principle or quota system as enshrined in Nigeria's Constitution since 1979, seeks to ensure that recruitment and appointments to public service organizations reflect the linguistic, ethnic, religious, and geographic diversity of the country. The Fundamental Objectives and Directive Principles of State Policy, Chapter two, Section 
14(3\&4) of the 1999 Constitution as amended states that:

The composition of the Government of the Federation or any of its agencies and the conduct of its affairs shall be carried out in such a manner as to reflect the federal character of Nigeria and the need to promote national unity, and also to command national loyalty, thereby ensuring that there shall be no predominance of persons from a few State or from a few ethnic or other sectional groups in that Government or in any of its agencies (FRN, 1999).

The composition of the Government of a State, a local government council, or any of the agencies of such Government or council, and the conduct of the affairs of the Government or councillor such agencies shall be carried out in such manner as to recognize the diversity of the people within its area of authority and the need to promote a sense-of belonging and loyalty among all the people of the Federation (FRN,1999).

Application of federal character and quota system in recruitment of civil servants as well as the military and paramilitary has confused striking a balance between merit and the quota. This has had adverse consequences for both institutions in terms of discipline, morale, and overall efficiency, productivity and service delivery. The basic idea of the principle is to have an even representation of all states, ethnic and other sectional groups in the federal service. It has a lot of political support, especially from those in the disadvantaged areas- mainly the northern states of Nigeria (Olowu, Otobo and Okotoni, 1997). In order to implement this concept effectively, a commission called the Federal Character Commission was created in 1995. The commission in collaboration with Federal Civil Service Commission and Ministries, Agencies and Commissions (MDAs) is to ensure that recruitment into federal civil service reflects federal character principle.

\subsection{The Nexus between Recruitment and Service Delivery}

It has been observed that the assumption underpinning the practice of human resources management (HRM) is that people are the organization's key resource and service delivery and organizational performance largely depends on them (Armstrong, 2009). Therefore, if an appropriate range of HR policy and process are developed and implemented effectively, HR will make a substantial impact on service delivery. Yet, Guest, Michie, Conway, and Sheenan (2003) posit that the case for an association between human resource management, service delivery and workers productivity are based on two arguments. The first one being that the effective deployment of human resources offers one of the most powerful bases of competitive advantage. The second argument is that effective deployment of human resources depends on the application of a distinctive combination of practices, or the use of a consistent set of human resource practices. Furthermore, Guest et al. (2003) stress that there is a plausible case that HR management will be more effective if it fits the business strategy of each organization.

According to Collins and Druten (2003), researchers have produced compelling evidence for the causal link between how people are managed and workers productivity and service delivery. They argue that the effectiveness of recruitment policy, particularly employee 
selection procedures, performance appraisals, rewards and benefits management, and employee training and development (the matching model of HRM) often have a direct bearing on workers productivity and service delivery. It has also been argued that, the result of effectively managing human resources is an enhanced ability to attract and retain qualified employees who are motivated to perform (Schuler and Macmillan, 1984). To them, the benefits of having the right employees motivated to perform include greater profitability, enhanced service delivery, low employee turnover, high product quality, lower production costs, and more rapid acceptance and implementation of corporate strategy. However, the application of federal character or quota system in recruitment in federal civil service negate this synergy

\subsection{Ecology of Recruitment in the Nigerian Federal Civil Service}

The ecology of public personnel policy in the federal civil service is influence by the peculiar nature of the Nigerian federation. The Nigerian civil service is the administrative machinery through which government implements its policies. It comprises ministries and extra ministerial departments, agencies, commissions and parastatals. Establishments within the ambit of the service have their administrative arrangements for recruitment and selection, training, transfer, secondment, promotion, discipline, salary administration, industrial relations and disengagement. However, public personnel policies that direct this practice reflect constraints which affect the productivity and service delivery of workers.

Ecological factors have influenced formulation of recruitment and selection policies in Nigeria. A significant ecological factor is the diverse and populous nature of the Nigerian society. These diversities and complexities are seen in the ethnic, cultural and religious dimensions. There are more than 252 known ethnic groups in Nigeria, each with its own dialects, customs and traditions (Osaghae, 2011). These features provide the rationale for Nigeria's adoption of a federal system of government, which is more difficult to run and maintain compared to other systems of government. This complex nature of the Nigerian society affects the harmonious relationship between formulators and implementers of public personnel policies.

In terms of analysis, the constraints of implementing public personnel policies on recruitment and selection in the Nigerian civil service could be traced to misconception of bureaucratic roles. Olowu et al. (1997) noted that over three decades after independence, the public service overtime lost its inherited commitment to political neutrality, professional and developmental meritocratic ethos.

Immediately after independence, the Nigerian state was faced with a situation where the political space was dominated by Northern elite, while the administrative machinery of the bureaucracy was dominated by the Southern intellectuals and intelligential. For the political executive to successfully carry out its policies, it required a facilitator in the bureaucracy, which the North was unable to provide in terms of people with required skills, educational qualifications and experience. In this regard, the South with more qualified human resources dominated the public bureaucracy. This meant that while the North dominated the political space, the South, on the other hand dominated the bureaucracy. It was in a bid to resolve the 
problem of Northern political domination and Southern dominated bureaucracy that gave birth to the introduction of representative bureaucracy that rides on the wing of "Federal Character Principle" (See for example Ayoade in Ibeto and Aremu, 2013). Thus, the 1999 constitution of the Federal Republic of Nigeria recognized the imperative of federal character to Nigeria's administrative system as provided in the section 14 (3) of the constitution.

The reason why the principle is considered more important than merit in the recruitment of federal civil servants is because those in the disadvantaged areas - mainly the .Northern part as opined by Olowu et al (1997) are the political leaders of the country. This made it possible for them to use their positions to protect their region using the principle. However, a new problem has since emerged in the area of quality of human resources in the public sector. While the Civil Service Commission appoints senior personnel on salary Grade level 07-17 to reflect the federal character and quota system, the various ministries and extra-ministerial departments appoint junior officers on Grade level 03 -06 under the delegation and supervision of the Civil Service Commission Decree 43 (1988) and Section 170 of the 1999 Constitution as amended.

The Nigerian civil service places a lot of premium on the interview method for selection, Decree 43 of 1988 states that "all eligible candidates for appointment shall be interviewed by the appropriate personnel management board or committee. Whatever the case, the principles of merit, that of quota system and federal character are always enforced to determine who to recruit and whom to select. This to a large extent and in the view of Nze (1988) downplays the inevitability of bureaucracies to efficiently and effectively deliver public goods and services. Competence and job specialization cannot thrive where sentiments are brought to play. In any case, successful candidates are notified through letters of appointment duly signed by an officer designated to do so by the ministry concerned or by the civil service commission.

There are several theoretical windows through which a subject matter could be examined, especially in social and management sciences where perspectives often differ based on scholar's orientation and worldview. It is in the light of the foregoing that we undertake this endeavor. When issues of recruitment policy and service delivery in the public service are raised in contemporary times, Max Weber (1947) bureaucratic theory which is one of the several comes out forcefully. Max Weber an influential German sociologist and greatest apostle of bureaucracy, viewed bureaucracy as a special form of administration that is fully developed in what he terms "the modern state" in "the most advanced institutions of capitalism" (Morrison, 2006). These forms of institutions have gradually been displacing traditional administrative systems.

Morrison (2006) claim that by observing the roles of officials within the legal-rational authority structures, one could identify the distinctive characteristics of bureaucracy, which is: a clear hierarchy of officials, clearly defined responsibilities and spheres of authority and officials appointed on the basis of merit (their competency and qualifications) to carry out their functions.

For Weber (1947) the ideal bureaucratic organization was essentially the well-designed 
machine within which all the component parts work efficiently and without distraction, towards clearly defined goals.

The bureaucratic theory is relevant and applicable to the study. Thus, the integration of bureaucratic theory in the study enable us have the bases for accessing the Nigerian federal civil service as regards recruitment policy of federal character and quota system and its implication on workers service delivery and productivity. The theory also enables us direct our search light for possible causes of poor service delivery and low productivity in the Nigerian public sector. The theory is relevant and applicable to the study based on the fact that the input (quality of applicants) determines the output (productivity and service delivery).

However, all theories are born refuted, bureaucratic theory is not an exception. The psychological consequences of the theory ignored individual goals and aspirations; it rather treated their goals as derivational that tend to subvert organizations rational needs and ends. Yet, tension between the authorities of position and skills is unexamined.

\section{Methodology}

In order to examine the application of federal character principle and its implication on service delivery in Nigerian federal civil service, this research employed the descriptive survey design, with the researcher setting out to illustrate the association that exists among the dependent and independent variables. The researcher's main goal in a descriptive study is to describe accurately the relationship between two phenomena (recruitment policy and service delivery). This method is useful because the study is interested in finding the meaning and to obtain an understanding of the issue under investigation.

The study relied heavily on primary and secondary data. To supplement the data from primary source, secondary materials were sourced from academic literature on the subject matter. In this regard, questionnaire were used as instrument for collecting primary data, closed ended questionnaires to be precise, where questions were structured in line with the research questions and hypotheses. The Liker five point rating scale questionnaire: Strongly Agree (5); Agree (4); Undecided (3); Strongly Disagree (2) and Disagree (1).

The respondents were requested to rate the items according to the extent to which they agree or disagree with the underlying attributes under measurement. A theoretical mean value of 3.0 was taken as a criterion to judge the means for the items in the respective sections. Therefore, any item in the instrument which had a mean equal to 3.0 or above was regarded as strongly agreed or to a large extent as the case may be, while items with less than 3.0 was regarded as small or disagreed.

Due to limited time, the researcher had to select two ministries with total staff strength of 1791 through the principle of randomization to constitute the study population (See table 3.1). The ratio 1:10 was used to reduce the ministries to two and the decision to limit the study to two ministries was based on the need to have a manageable sample. Moreover, two ministries approximately are above 10 percent of the whole population. This is in line with the law of small and large numbers. As noted by Best and Khan (2006), a sample equal or above 10 
percent is valid to generalize results for the whole population. Thus, it was deemed a representative sample with regards to the research purpose and considering the fact that the problem under investigation appear or manifest the same way in all the Nigerian civil service. Therefore, the findings can be used to make inferential judgement on the entire civil service.

Table 1.1 Ministries Selected for the Study

\begin{tabular}{|l|l|l|l|l|}
\hline S/n & Ministries & Junior Staff 03-06 & Senior Staff 07-17 & Total \\
\hline 1 & Ministry of Information & 621 & 264 & 853 \\
\hline 2 & Ministry of Justice & 667 & 271 & 938 \\
\hline & Total & & & 1791 \\
\hline
\end{tabular}

Source: Federal Civil Service Commission (FCSC), 2014

Given the population of about1791 civil servants from the two ministries chosen for this study, the sample size using Yamane's (1967) formula for sample size determination was used select 327 respondents.

The study adopted the simple percentage statistical method of analyzing the responses. Simple percentage entails using the diverse response from respondents in categorizing them and thereby drawing the represented percentage for each of the group. Consequently, in order to test the hypotheses and establish the degree of dependence or independence of the variables under consideration, the chi-square statistical tool was used for this study. The results of the returned questionnaires were captured on Microsoft Excel and then exported to Statistical Packages for Social Science (SPSS) for analysis and interpretation. The results were later used to draw deductions and conclusions on the subject matter of study in the concluding section.

\section{Data Presentation, Analysis and Interpretation}

This section presents and analyses the data collected in the course of the study. Issues relating to the demographic data of respondents, the nature of federal character, recruitment and its implications on workers service delivery and productivity were are presented as well as testing of the two research hypotheses.

\subsection{Demographic Data of Respondents}

The sex distribution of the respondents shows that, 67.6 percent of the respondents were male while 32.4 percent were female. This result shows that male were more than female in the polled respondents. The length of service shows that 47.6 percent of the respondents had put in between 5-10 years in the service; 34.6 percent had put in between 11-20 years while 18.4 percent had served for between 20 and above. This shows that majority of the surveyed 
workforce has put in between 6-15 years of service, the implication is that majority of them still have more years before retiring because of the present policy which sets retirement age for civil servants at 35 years of service or 60 years of chronological age whichever comes first. The official status of respondents indicates that 63.2 percent were junior staff while 36.8 percent were senior staff. This shows that junior staffs were more than the senior staff in the polled respondents. The educational qualifications reveal that 33.7 percent of the respondents had postgraduate degree while 36.2 percent had first degree/HND, with another 20 percent who had NCE/ND. 10.2 percent of the respondents had WASC/SSC/NECO. Evidentially, majority of the respondents had acquired one skill or the other.

\subsection{Presentation of Data According to Research Variables}

This section analyzed the research questions and research hypotheses.

The nature of federal character principle in the recruitment of civil servants and employees ${ }^{\text {ee }}$ service delivery in the Nigerian federal civil service

Table $1.3(\mathrm{n}=315)$

\begin{tabular}{|l|l|l|l|l|}
\hline S/n & Variables & Mean & Std Dev & Decision \\
\hline 1 & Federal character enhance service delivery & 2.5448 & 0.96466 & Disagreed \\
\hline 2 & Reward for hard work & 2.9478 & 0,906222 & Disagreed \\
\hline 3 & Increase in efficiency and effectiveness & 2.9104 & 0.97890 & Disagreed \\
\hline 4 & Visitors are attended to without delay & 2.5373 & 0.96498 & Disagreed \\
\hline 5 & Federal character ensure employment equity & 2.7276 & 1.02244 & Disagreed \\
\hline & Grand mean & 2.8108 & 0.52186 & Disagreed \\
\hline
\end{tabular}

Source: Field Survey May, 2014

The respondents as could be seen in the table 4.1 above disagreed in all the items depicting the effects of recruitment policy of federal character principle as regards service delivery in the federal civil service. All the 5 items in the table have mean rating of less than 3.0. Thus, the surveyed respondents disagreed that federal character principle enhances service delivery, hard working employees are rewarded, increase in efficiency and effectiveness and clients being attended to without delay as well as employment equity which the framers of constitution sighted as the reason for its adaptation.

Beside this, an interview with some civil servants further revealed how angered and dissatisfied they were. Some complained bitterly on how some staff they joined the service earlier than and are better than on the job, happens to be their boss or superior as a result of 


\section{Macrothink}

International Journal of Human Resource Studies

ISSN 2162-3058

2015, Vol. 5, No. 3

federal character principle. The implication here is that such employees may not put in their best as regards service delivery in the service. In fact they may even sabotage the system.

The effect of federal character principle in the recruitment of federal civil servants as regards employees ${ }^{\text {ee }}$ attitude to work in the Nigerian federal civil service

Table $1.4(\mathrm{n}=315)$

\begin{tabular}{|l|l|l|l|l|}
\hline S/n & Variables & Mean & Std Dev & Decision \\
\hline 1 & Federal character enhance national integration & 3.0970 & 0.71756 & Agreed \\
\hline 2 & Federal character ensure organizational stability & 2.9142 & 0.89322 & Disagree \\
\hline 3 & $\begin{array}{l}\text { Federal character abolish employment } \\
\text { discrimination }\end{array}$ & 2.8 .97 & 0.96239 & Disagree \\
\hline 4 & Federal character boost employee attitude to work & 2.5373 & 0.96498 & Disagree \\
\hline & Grand mean & 2.9224 & 0.54266 & Disagreed \\
\hline
\end{tabular}

Source: Field Survey May, 2014

A cursory look at the table 4.3 above shows that the respondents only agreed to item one item based on the mean rating of 3.0 and above. Indeed, they agreed that federal character or quota system ensure employment equity. They however, disagreed that federal character ensure organizational stability, abolished employment discrimination, boost employee work attitude.

Yet, in the course of the interview, some key stakeholders buttress the fact that with quota system in the recruitment of federal civil servants, the much desires productivity and service delivery in the public service will for long remain a mirage. It is along this line of thought that El-Rufai (2012) argued that the Nigerian civil service has been short sighted in vision, self centered in policy making and implementation. He went further to posit that the civil has focused on taking care of its interest to the determent of the system that sustains it.

\subsection{Test of Hypotheses}

It will be recalled that the study identified a number of hypotheses. It will at this juncture test them one after the other using person chi-square test of goodness of fit with the aid of SPSS package.

\section{Hypothesis I}

H0: The application of federal character principles in the recruitment of civil servants has a negative effect on employees ${ }^{\text {ee }}$ service delivery in the Nigerian federal civil service.

H1: The application of federal character principle in the recruitment of federal civil servants has a positive on employees ${ }^{\text {ee }}$ service delivery in the Nigerian federal civil service. 


\section{Cross tabulation}

Count

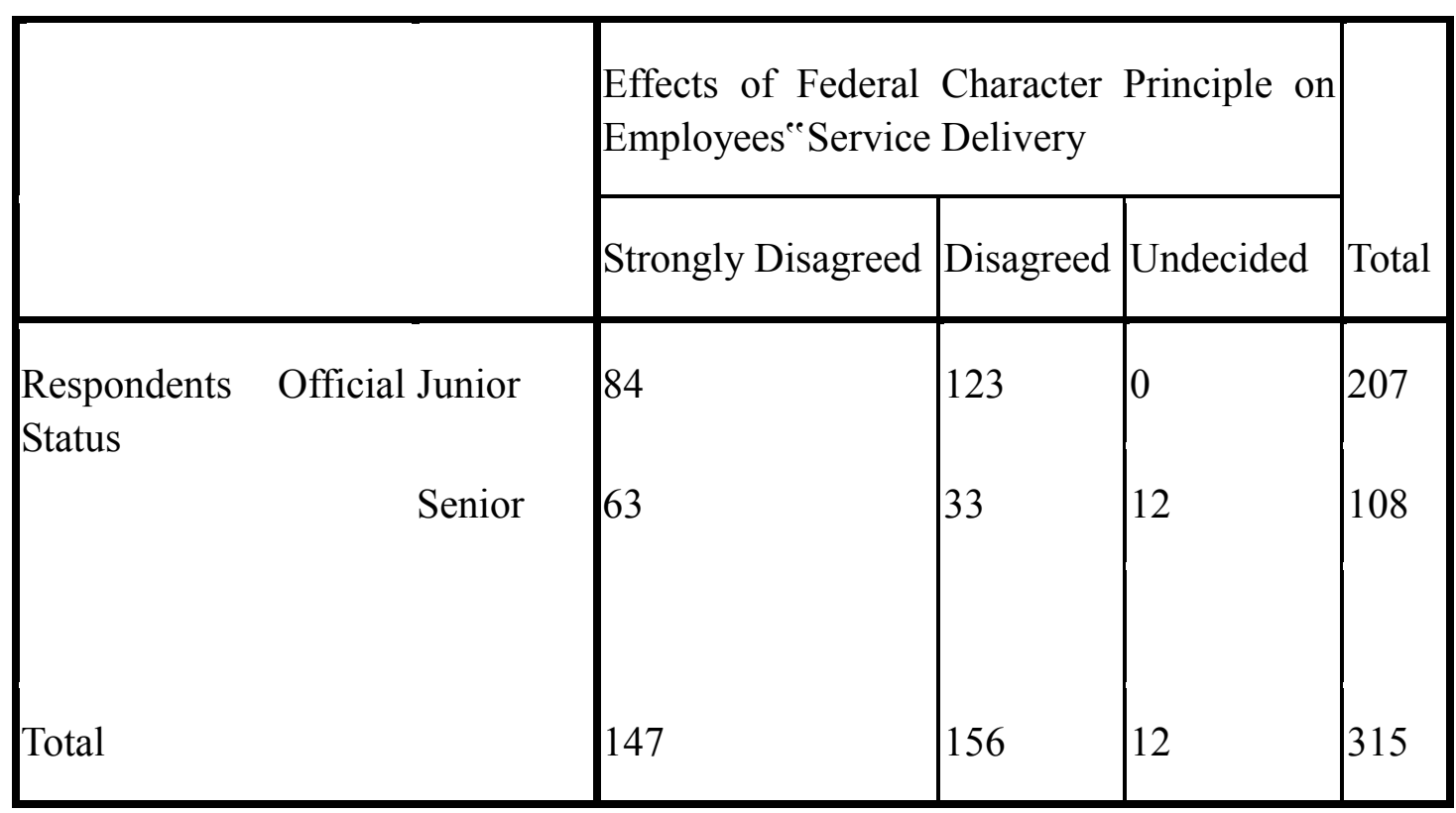

Chi-Square Tests

\begin{tabular}{|l|l|l|l|}
\hline & Value & Df & $\begin{array}{l}\text { Asump. Sig. } \\
\text { (2-sided) }\end{array}$ \\
\hline Pearson Chi-Square & $181.220^{\mathrm{a}}$ & 4 & .000 \\
Likelihood Ratio & 138.678 & 4 & .000 \\
Linear-by-Linear & 118.518 & 1 & .000 \\
Association & 315 & & \\
\hline
\end{tabular}

a. 2 cells $(22.2 \%)$ have expected count less than 5 . The minimum expected count is 2.33 .

Research Result: From the computation above, the chi-square calculated $\left(\mathrm{X}^{2} \mathrm{c}\right)$ is 138.678 while the chi-square tabulated $\left(\mathrm{X}^{2} \mathrm{t}\right)$ is 181.220 . Thus, the chi-square calculated is less than chi-square tabulated. On the basis of this, the study therefore rejects the alternative 


\section{Macrothink}

International Journal of Human Resource Studies

ISSN 2162-3058 2015, Vol. 5, No. 3

hypothesis and accepts the null hypothesis and concludes that the application of federal character principle in the recruitment of federal civil servants has a negative effect on employeese service delivery.

Policy Implication: The policy implication of the result of hypothesis one which states that the application of federal character principle in the recruitment of federal civil servants has a negative effect on employees service delivery is that the country's image as well as national development is at stake if federal character is not limited to a minimum acceptable standard. This is supported by Cook (in Motsoeneng, 2011) who argues that competent and qualified candidates are twice as more productive as less qualified candidates and that appointing less qualified candidates is costly to an organization because they are less productive. Therefore, it is imperative to re-examine the reliability and validity of these recruitment and selection instrument in the Nigerian federal civil service.

\section{Hypothesis II}

H0: The application of federal character principle has a negative effect on employeese attitude to work in the Nigerian federal civil service.

H1: The application of federal character principle has a positive effect on employees ${ }^{\text {ee }}$ attitude to work in the Nigerian federal civil service.

\section{Cross tabulation}

Count

\begin{tabular}{|c|c|c|c|c|c|}
\hline & \multicolumn{4}{|c|}{$\begin{array}{l}\text { Effects of Federal Character Principle on } \\
\text { Employees }{ }^{\text {ee }} \text { Work Attitude }\end{array}$} & \multirow[b]{2}{*}{ Total } \\
\hline & Agreed & Undecided & Disagreed & $\begin{array}{l}\text { Strongly } \\
\text { Disagreed }\end{array}$ & \\
\hline Official Junior Staff & 7 & 0 & 122 & 53 & 182 \\
\hline Senior Staff & 4 & 7 & 33 & 89 & 133 \\
\hline Total & 11 & 7 & 155 & 142 & 315 \\
\hline
\end{tabular}




\section{Chi-Square Tests}

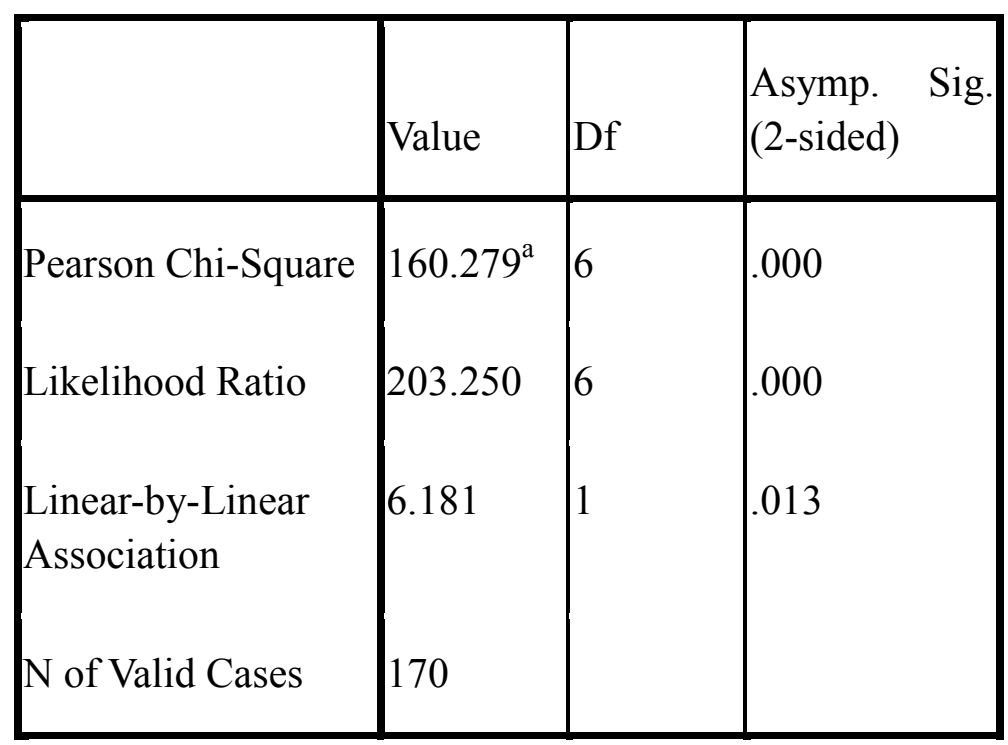

a. 5 cells $(41.7 \%)$ have expected count less than 5 . The minimum expected count is 1.36 .

Research Results: From the computation above, the chi-square calculated $\left(X^{2} c\right)$ is 160.279 while the chi square tabulated $\left(X^{2} t\right)$ is 203.250 . Thus, the chi-square calculated is less than chi-square tabulated. On this basis, we therefore accept the null hypothesis and reject the alternative hypothesis and concluded that the application of federal character principle has a negative effect on employees ${ }^{\text {ee }}$ attitude to work in the Nigerian federal civil service.

Policy Implication: The policy implication of the result of hypothesis two which states that the application of federal character principle has a negative effect on employeese attitude to work in the Nigerian federal civil service is that such a policy and practice create room for recruitment of incompetent applicants into the civil service thereby making the system unproductive and at the same time inhibiting national growth and development. This is in line with the position of Igbokwe-Ibeto, and Aremu (2013); and Ukaegbu (1995) that numerous inventions, innovations, planning, policy implementation, management, assembly line production, service delivery, farming, etc. in developed countries are results of efficiency. Therefore, a theory of productivity is eventually a theory of national development. The immediate priority for policy makers therefore is to re-examine the reliability and validity of these federal character or quota system as a recruitment policy in the federal civil service.

\section{Discussion of Findings}

In view of the research questions and the subsequent testing of the two stated hypotheses, the study revealed that the application of federal character principle in the recruitment of public servants in Nigeria has affected worker service delivery and productivity coupled with the fact that competent workers are not rewarded. The study also revealed that inefficiency and ineffectiveness in service delivery as result of poor quality workers occasioned by federal character based recruitment is still evident in the civil service. 
Employment equity is one of the reasons canvassed by the proponents of federal character and quota system. However, the result of the study is contrary to that as the mean rating is less than 3.0. Thus, respondents disagreed with that federal character ensures employment equity.

The study also revealed that federal character has increased national integration as many ethnic groups can be seen working in federal establishments in various parts of the country. However, the study did not find a correlation between federal character principle and organizational stability. Yet, the study also discovered that federal character principle has failed to alter employment discrimination and equity in Nigerian federal civil service.

Another finding of the study is that federal character inhibits workers productivity and reduces workers morale as a result of recruitment of incompetent and inefficient workers into the federal civil service. This is against the tenets of Weber's bureaucratic theory that stipulates recruitment or appointment of official based on merit, technical competency and qualification. The importance of recruiting competent employees is supported by Cook (in Motsoeneng, 2011) who argues that the rational estimate technique is an important tool that assists supervisors to make ideal matches between subordinates ${ }^{\text {ee }}$ competencies and skills and job requirements. Cook went further to state that a competent employee would be at the 2 nd percentile, and one who is poor would be at the 4th percentile. Since these values correspond roughly to one standard deviation on either side of the mean, an employee at the 4th percentile is two deviations above the mean. It means that the best employees are twice as good as poor employees. The standard deviation is crucial in the equation for estimating the return on a recruitment programme, since the smaller the standard deviation, the less the difference in value between good and poor employees and similarly, the bigger the standard deviation, the greater the difference between best and poor employees. Government can save money by engaging competent and qualified employees; the better the fit, the higher the employee's productivity and the greater his or her contribution towards enhancing service delivery.

The first hypothesis tested shows that there is a significant relationship between principles of federal character and employees ${ }^{e e}$ service delivery. This is evident in the chi-square calculated $\left(\mathrm{X}^{2} \mathrm{c}\right)$ that is 181.220 while the chi-square tabulated $\left(\mathrm{X}^{2} \mathrm{t}\right)$ is 138.678 . Thus, the chi-square calculated is greater than chi-square tabulated. The study therefore, rejected the null hypothesis. Relative to federal character principle or quota system as recruitment policy, they are seen by employers as an unsavoury strategy for rectifying the effects of past or present unfair discrimination (Cascio, 1986). The major problem associated with this principle as observed in the survey is that the principle sacrifices merit in favour of quota. For instance, a respondent in a personal interview was disappointed with the principle stating that the countryes image is at stake if the federal character is not limited to minimum acceptable standard.

According to the respondent, "the worst of it is that the principle is also applied in the secondment of Nigerians for foreign services". It was discovered in the study that the reason why the principle is considered more important than merit in the recruitment of federal civil 
servants is because those in the disadvantaged areas - mainly the Northern parts as opined by Olowu et al (1997) were the political leaders of the country. This made it possible for them to use their positions to protect their region using the principle. For instance, in the Northern Governors Forum (NGF) of 2007, Mu'azu Babangida Aliyu (Niger State Governor) said that "one of the problems facing the region is education backwardness. Despite this problem, the study observed that people from the Northern region are significantly placed in the federal civil service because of the utilization of federal character principle plus the number of states in the region. This often led to recruitment of incompetent applicants which is one of the major reasons responsible for low productivity and poor service delivery in the federal civil service (See for example Briggs, 2007). The implication of this is the position of Pearson (2005), that managers will always recruitment people that look like them.

On the test of the second hypothesis, the result shows that there is a significant relationship between principles of federal character and employees ${ }^{\text {ee }}$ productivity. This is evident in the chi-square calculated $\left(X^{2} c\right)$ that is 203.250 while the chi square tabulated $\left(X^{2} t\right)$ is 160.279. Thus, the chi-square calculated is greater than chi-square tabulated. The study therefore, rejected the null hypothesis and accepts the alternative hypothesis.

The quality of workers in any given organization to an extent determines the degree of success to be achieved. This is supported by Oshionebo (1992) citing Rensis Likert who argues that every aspect of a firm's activities is determined by the competent, motivated, and general effectiveness of its human organization. Of all the task of management, managing the human component is the central and most important task, because all else depends upon how well it is done (in Oshionebo, 1992). The adoption of federal character principle that compels governments at all levels to ensure spread in the recruitment and appointment of personnel into civil service has not helped the system. Although, this is not a bad provision in a federal state like Nigeria, but because of paucity of quality candidates in some states of the federation, less qualified people are given positions not suitable for them and in the final analysis, it is the public interest (service delivery) and productivity that suffers.

\section{Conclusion and Recommendations}

With the Weberian prescriptions of the ideal bureaucratic theory underlying the foundation for this study, it is posited that for governments to operate the most efficient and effective administrative organization that would be beneficial to all, her recruitment policy into the federal civil service should be unfettered. It should also be capable of absorbing the best qualified, technically competent, disciplined and committed personnel that would in turn help government to achieve the goals of governance and administration. It was concluded from the findings of this study that Nigerian civil service is faced with poor recruitment policy which have affected service delivery in civil service.

In view of the literature review and findings of this study, it is clear that the ball now lies solely on federal government to make amendments to federal character principle as regards recruitment of workers. To achieve greater public goods and service delivery in the Nigerian federal civil service, the following is recommended: 


\section{Macrothink}

International Journal of Human Resource Studies

ISSN 2162-3058

2015, Vol. 5, No. 3

Nigerian civil service should imbibe the prescripts of Marx Weber bureaucratic theory as regards recruitment and global best practices that place preference on recruitment based on merit, technical competency and qualification. To achieve better employee work attitude in the Nigerian federal civil service, it is imperative to re-examine the reliability and validity of the application of federal character principle. Application of federal character principle in recruitment should be contextualized within grade levels (03 -06) while recruitment into senior officers cadre and appointment should be strictly based on merit

\section{References}

Akhakpe, I.P. (2014), Bureaucracy and Good Governance. Lagos: Pumark Publishers.

Akhakpe, I., Fatile, O.J and Ibeto, .J. (2012), "Delivering Efficient Public Service in Nigeria through Better Performance Management Frameworks", International Journal of Social Sciences and Humanities Review, 3(I):182-195.

Anazodo, R.O, Okoye, J.C, and Chukwuemeka, E.O. (2012), "Civil Service Reforms in Nigeria: The Journey so far in Service Delivery", American Journal of Social and Management Sciences, 3(1):17-29. Armstrong, M. (2009), A Handbook of Human Resource Management Practice, London: Kogan Page Limited.

Asika, N. (2002). Research Methodology in the Behavioural Sciences, Lagos: Longman Nigeria Plc.

Babaru, A.S.M. (2003), "Leading Public Service Innovation", in New Zealand Agency for International Development (NEAID), Monday, February $24^{\text {th }}-26^{\text {th }}$ March, p. 26

Babbie, E and Mouton, J. (2001), The Practice of Social Research, Cape Town: Oxford University Press.

Basu, R. (2004), Public Administration, Concept and Theory, New Delhi: Sterling Publishers.

Best, W. and Kahn, V. (2006), Research in Education, Essex: Person Education.

Bodunrin P. (1989), "Federal Character and Social Justice", in Gberevbie A. (eds.), Strategies for Employee Recruitment, Retention and Performance: Dimension of the Federal Civil Service of Nigeria, http//www.academic [ournal.org. Retrieved: 6/3/2014.

Briggs, R.B. (2007), "Problems of Recruitment in Civil Service: Case of the Nigerian Civil Service", African Journal of Business Management, I(6):142-153

Cascio, W.F. (1986), Managing Human Resources: Productivity, Quality of Work Life, Profits, London: McGraw-Hill International Editions, Management Series.

Collins, R. And Druten, K. (2003), Human Resource Management Practices. Retrieved fromhttp://www.edu.au/agsm/web.agsm.nsf/AttachmentByTitle/CCHREPORT2003/\$FILE/C 26/11/2013.

El-Rufai, N, (2012). Refining our Dysfunctional Public Service, 
htt/www.elombeh.com/indexpub. Accused 23/4/2014.

Eneanya, A.N. (2009), Principles and Practice of Public Personnel Administration in Nigeria, Lagos: Concept Publications Limited.

Erasmus, B, Swanepoel, B, Schenk, H, Van der Westhuizen, E and Wessels J.S. (2005), South African Human Resource Management for the Public Sector, Cape Town: Juta.

Ezeibe, C. C (2013) . "Federal Character Principle and Nationality Question In Nigeria", International Journal of Research in Arts and Social Sciences (IJRASS)

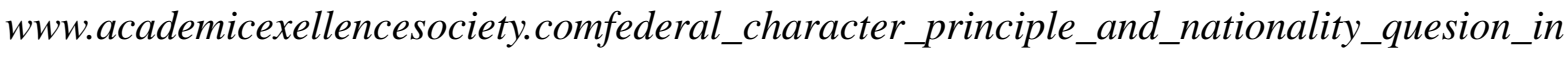
_nigeria.html Retrieved 14/6/2014.

Ezenwa, U (1987). "Participatory Politics: The Socio- Economic Dimension" NIPSS Conference proceeding.

Federal Republic of Nigeria (FRN, 1998), Guidelines for Appointments, Promotion and Discipline, Abuja, Issues by the Federal civil Service Commission.

Federal Republic of Nigeria, (FRN) (1999), The Constitution of Nigeria as Amended, Section 14, Subsection 3, Lagos: Government Printers.

Franz, U. (2011). "Service Delivery Concepts and the Namibain Situation" Workshop on Achieving Benefits of Enhanced Service Delivery by National Metrological Services (NMSs) in Eastern and Southern Africa.

Gerber, P.D, Nel, S and Van Dyk, P.S. (1992), Human Resource Management, Halfway House: Southern Books

Guest, D. E., Michie, J., Conway, N., and Sheenan, M. (2003), "Human Resource Management and Corporate Performance in the UK", British Journal of Industrial Relations, 14(2): $291-314$.

Heirmexxy, G. (2011). "Federal Character Policy and Technology Development in Nigeria; Problems and Prospects ${ }^{\text {eee }}$ Retrieved from www.Pristinethrills.blogspot.com/2011/03/ federal-character-policy-and-technology/html 20/05/2014.

Igbokwe-Ibeto, .J and Aremo, M.O. (2013). "Federal Character and Recruitment in the Nigerian Civil Service: Prospects and Implications", Global Journal of Applied, Management and Social Sciences, 1(3):34-45.

Kolawole, D. (2008), "From Policy to Result-based Implementation" Being the text of a Guest Lecture Delivered on Thursday $11^{\text {th }}$ Sept., 2008 to mark the 2008 Civil Service Week Celebration held at Ado-Ekiti, Ekiti-State.

Mapira, N., Katsuro, P., Chazuza, T., Mlingwa, M.M., Togarepi, M., Mutambatuwisi, F., Nhimba, N.K., Umera, T and Machigere, T. (2013), "The Importance of Establishing Job a Analysis Exercise in an Organisation: A Case Study of Bread Manufacturing Companies in Zimbabwe", Australian Journal of Business and Management Research, 2(11):35-42. 
Mukoro, A. (2005), "Ecology of Recruitment and Selection of Personnel in the Nigerian Federal Civil Service”, Journal of Human Ecology 17(1):31-37.

Morrison, K. (2006). Marx, Durkheim, Weber: Formations of Modern Social Thought. London: Sage.

Motsoeneng, R.P. (2011). Recruitment Policies and Practices in the Department of Public Service and Administration, Unpublished M.A Project Department of Public Administration, University of South Africa. http://www.rci.rutgers.edu/schuler /ainpages/gaining Compadvantagehrmpractices.27/10/2013.

Nickels, W.G, McHugh, J.M, McHugh, S.M. (1999), Understanding Business, New York: Irwin/McGraw-Hill.

Nze, F.C. (1988), "Administrative Reforms in two Political Cultures: A Comparative Study of Nigeria and the US", The Nigeria Journal of Public Affairs, 12(1):60-71.

Okorie, C.O and Greg, E (2013). "Federal Character Principles, Nation Building and National Integration in Nigeria: Issue and Options", Mediterranean Journal of Social Sciences, 4(6):33-39.

Olagunju, T (1987). "Federal Character and National Integration”, Conference Proceedings, National Institute for Policy and Strategic Studies (NIPSS) Jos, Plateau State.

Olowu, D., Otobo, E. and Okotoni, M. (1997), The Role of the Civil Service in Enhancing Development and Democracy: An Evaluation of the Nigerian Experience. Paper presented at Civil Service Systems in comparative perspective, School of Public and Environmental Affairs, Indiana University, Bloomington, Indiana, April 5th $-8^{\text {th }}$.

Olu-Adeyemi, L. (2009), "Public Administration Reform in Nigeria" in R.F Ola and D.A Tonwe (Eds.), Nigerian Public Administration, Lagos: Amfitop Books.

Olusanya, G.O. (1975). The Evolution of the Nigerian Civil Service (19861-1960): The Problem of Nigerianization, Lagos: University of Lagos Press.

Omotade, D. (1992). "Formulation and Implications of Personnel Policy in the Civil Service" in A.D. Yahaya and I. C. Akinyele (Eds.), New Trends in Personnel Management: A Book of Reading, Badagry: Administrative Staff College.

Oronsaye, A.O. (2009). "Tradition and Trends in Nigerian Public Administration", in R.F Ola and D.A Tonwe (Eds.), Nigerian Public Administration, Lagos: Amfitop Books.

Osaghae, E. (2011), The Crippled Giant: Nigeria Since Independence, Ibadan: John Archairs Publishers.

Oshionebo, B. O. (1992), "An Overview of Management and the Personnel Function" in A.D. Yahaya and I. C. Akinyele (Eds.), New Trends in Personnel Management: A Book of Reading, Badagry: Administrative Staff College.

Peretomode, V.F, Peretomode, O. (2001), Human Resources Management: Principles, 


\section{Macrothink \\ International Journal of Human Resource Studies \\ ISSN 2162-3058 2015, Vol. 5, No. 3}

Policies and Practice, Lagos: Onosomegbowho Ogbmaka Publishers.

Robert, G. (2005), Recruitment and Selection, London: Institute of Personnel Development Publishers.

Schuler, R. S. and Macmillan, I. C. (1984), Gaining Competitive Advantage through Human Resource Management Practices. Retrieved from http://www.rci.rutgers.edu/schuler lainpages/gainingCompadvantagehrmpractices.27/10/2013.

Solaru Parliamentary Committee on Nigerianization (1958), Lagos: Federal Government Printer.

Ukaegbu, C.C. (1995), "Work Content in the Nigerian Civil Service", Nigerian Journal Public Administration and Local Government, 6(1):44-55.

Van der Westhuizen, E.J. (2005), "Managing People in the Twenty-first Century: Integrative Public Human Resources in Sub-Saharan Africa”, Politeia 24(11):118-120.

Weber, M. (1947), The Theory of Social and Economic Organization Translated by A.M.B Henderson and T. Parsons, New York: Free Pres.

Yamane, T. (1967). Statistics: An Introductory Analysis. India: Yani Publisher. 